\title{
Financial Challenges and the Subjective Well-being of First-year Students at a Comprehensive South African University
}

Marinda Pretorius ${ }^{\star} \&$ Derick Blaauw ${ }^{\star \star}$

\begin{abstract}
Since 1994, there has been a doubling in the enrolment of students in South Africa's public universities. Students, especially first-generation students, face numerous challenges that may impact their subjective perceptions of their well-being. In a milieu of high levels of suicide and depression amongst South Africa's student population, the understanding of the variables determining students' subjective well-being (SWB) should be deepened. This article investigates the levels and changes in the SWB of successive groups of first-year students at a comprehensive university in South Africa between 2014 and 2017. It makes use of a fit-for-purpose survey instrument. The results show that the SWB of students is influenced positively by their living arrangements and variables that have a direct influence on the educational environment in which they operate, such as feeling 'at home' and an overall level of satisfaction of the students' experience at the university. Negative variables that influence the SWB of students include concerns regarding finances and upcoming tests, and living on campus or within walking distance of campus.
\end{abstract}

\section{Keywords}

determinants; happiness; subjective well-being; university students

\section{Introduction}

In South Africa, 2015 may be remembered along with 1976 as a year in which students demonstrated their ability to alter the course of education history. The \#FeesMustFall campaign forced government to reflect on the various challenges facing the higher education sector in South Africa. Decades of rapidly expanding access, along with decreasing government subsidies, led higher education institutions to face a number of challenges. Higher education institutions must attempt to meet enrolment targets, but at the same time ensure quality education (Simkins, 2016).

Many of the students currently enrolled at higher education institutions are firstgeneration students, whose parents and families are making significant sacrifices for them to be amongst the more than 1 million students in South Africa. Students who were able

* Dr Marinda Pretorius is a Senior Lecturer in the School of Economics at the University of Johannesburg, South Africa. Email: marindap@uj.ac.za

** Prof. Derick Blaauw is a Professor in the School of Economic Sciences at the North-West University, South Africa. Email: derick.blaauw@nwu.ac.za 
to secure a spot at one of South Africa's higher education institutions face a myriad of challenges that may impact their lives and subjective perceptions of their well-being. This is especially true for first-generation students. They have no prior familial experience of higher education and, as a result, no reservoir of knowledge upon which to draw as to how to adapt to their new lives (Christie, Tett, Cree, Hounsell \& McCune, 2008). As a result, strong emotions of displacement, anxiety and guilt can all be part of the daily lives of first-generation students, alongside the more accepted emotional responses of hopeful anticipation, pleasure and enhanced self-esteem (Christie et al., 2008).

Subjective well-being (SWB) encompasses a person's present assessment of his/ her satisfaction with life and happiness (Dave, Tripathi, Singh \& Udainiya, 2011). The application of SWB in the field of economics has gained momentum during the last few decades. According to MacKerron (2012) SWB is linked to economics through macroeconomic issues as well as behavioural, environmental and ecological economics. The increasing connection with economics is indicative of a necessary move towards "more realism in the study of economic behaviour and provides an interface with psychological and sociological aspects underlying economic choices" (Blaauw \& Pretorius, 2013, p. 180).

Although theory suggests that students should have higher levels of subjective well-being (SWB) than, for example, the urban poor (Cox, 2012), this may not necessarily be the case within the context of the burden of expectations on students. The daily realities of being a student include struggles to afford food, accommodation, study material and other necessities for their optimal functioning. The issues of general student well-being, and specifically mental health, have become prominent in higher education in recent years (Luescher, Schreiber \& Moja, 2018). Data collected from more than 1300 South African students in 2013 revealed that not only are rates of suicidal ideation higher amongst these students than the general population, but they are also higher than student populations in other parts of the world (Bantjes, Kagee, McGowan \& Steel, 2016).

The high levels of depression and even suicide amongst South Africa's student population provide prima facie evidence that our understanding of the variables determining students' subjective well-being is in urgent need of re-evaluation and deepening. Bantjes et al. (2016) strongly suggested that more research is needed to investigate the psychosocial variables associated with these phenomena, especially within the cultural and socioeconomic context of South Africa.This article attempts to adhere to this call by investigating the levels and changes in the SWB of successive groups of first-year economics students at a comprehensive university ${ }^{1}$ in the heart of Gauteng between 2014 and 2017. Students at comprehensive universities come from diverse schooling backgrounds with unique characteristics and circumstances facing them (Pretorius \& Blaauw, 2014).

Improving our understanding of the daily lives of students can assist universities in improving their proactive strategies to assist first-year students in their transition

1 A comprehensive university in the South Africa context can be defined as a university that offers a combination of theoretically-oriented university degrees as well as vocational oriented diplomas and degrees (HESA, 2005). 
into university life (the first-year seminar is a good example of one of these strategies), increasing the likelihood of academic success to the benefit of the student and institution alike. Furthermore, the study may help to identify a broad range of relevant and topical issues concerning students and their outlook on life in South Africa's higher education sector. It is with good reason that Luescher et al. (2018) point out that student affairs in particular are implicated in finding solutions to the issues identified in current research.

The remainder of the article will discuss the relevant literature, choice of research population, research design and empirical strategy. This is followed by the results, discussion as well as possible policy implications and avenues for further research in this important field of study for South Africa's higher education landscape.

\section{Relevant Literature: Students and Subjective Well-being}

The study of happiness and subjective well-being is an ever-growing area of research in economics (Kahneman \& Krueger, 2006; Mangeloja \& Hirvonen, 2007, p. 26). The evolvement of studying subjective well-being within the realm of economics can be traced back to the seminal work of Richard Easterlin (1974; 2001). The body of literature that has emerged since then is comprehensive and concludes that the notion of subjective well-being is linked to a range of socioeconomic and other cultural features of countries around the globe (Diener, Diener \& Diener, 2009). ${ }^{2}$ Economists have focused their attention in this field on the relationship of subjective well-being and aspects such as earnings, economic growth, income inequality, inflation, institutions, human development index, consumption, globalisation and unemployment (Mangeloja \& Hirvonen, 2007, p. 26).

The study of subjective well-being falls within the broader strand of literature on psychological and social well-being, known as the hedonic approach of studying well-being (Negovan, 2010). The hedonic approach looks at well-being in terms of happiness and of the experience of pleasure combined with the absence of pain (Negovan, 2010).

Within this approach, numerous prior studies have investigated the determinants of quality of life (QoL) or subjective well-being amongst university and college students; however, this is mostly within a developed country context (Botha, Snowball, De Klerk \& Radloff, 2013; Pretorius \& Blaauw, 2014). Even in developed countries, the fulfilment of basic needs is the cornerstone of explaining students' subjective well-being (Türkdoğan \& Duru, 2012). The key assumption here is that emotions such as happiness can only be experienced if human needs are sufficiently met (Türkdoğan \& Duru, 2012). Interestingly, the needs for freedom, fun and power tend to be more important in this regard than the other basic needs such as the need for survival, love and belonging (Türkdoğan \& Duru, 2012). Chow (2005) found similar results in a study amongst students in Canada. As expected, basic needs such as housing conditions were statistically significant in explaining their general quality of life. Notably, however, the impact was smaller than other variables, such as self-esteem, relationship with a significant other, socioeconomic status, academic

2 See, for example, Frey's and Stutzer's (2002) book titled Happiness and Economics as well as Dolan, Peasgood and White (2008) for an extensive and well-documented overview of these factors and determinants. 
success and financial security (Chow, 2005; Michalos, 2008; Flynn \& MacLeod, 2015). These findings are supplemented by further studies that show similar results, but add explanatory variables related to the quality of teaching and resources available to students (Chan, Miller \& Tcha, 2005; Nielsen, Newman, Smyth, Hirst \& Heilemann, 2017).

Chan et al. (2005) studied the possible determinants of happiness amongst students at the University of Western Australia in 2003. Using an ordered probit model (which accommodates for the ordered nature of the SWB dependent variable), they found possible linkages between happiness and a set of variables. These include grades, friendships developed, school facilities, opportunities to participate in extracurricular activities, and lecture quality. School work, time management and relationships formed in university proved to be the most significant of these (Chan et al., 2005). Mangeloja and Hirvonen (2007) compared their results with the Chan et al. (2005) study and found similar results. The most significant effects on the students' levels of satisfaction were social relationships, resources available to them, as well as the broader educational environment and extracurricular activities.

The broader education environment and its influence on the subjective well-being of students do not function in a vacuum. Nielsen et al. (2017) recently studied the influence of instructor support, family support and psychological capital on the subjective well-being of postgraduate business students in Australia. They defined the personal psychological capital (PsyCap) of students as their "personal psychological resources of self-efficacy, hope, resilience and optimism” (Nielsen et al., 2017, p. 2099). They found positive relationships between instructor support and subjective well-being, as well as between PsyCap and subjective well-being (Nielsen et al., 2017). Furthermore, PsyCap mediated the association between instructor support and subjective well-being. Family support, on the other hand, moderated this mediated relationship so that the relationship was stronger amongst students with lower levels of family support (Nielsen et al., 2017).

Furthermore, the unique demands and pressure of university life are also an important consideration in studying students' subjective well-being. Eckersley (2011) states that in Australia, $48 \%$ of university students were psychologically distressed and many faced the risk of developing mental disorders. According to Eckersley (2011), national surveys of American college students revealed similar results. Nine in ten American college students reported that they often feel overwhelmed by all they had to do and felt exhausted, anxious, angry and depressed.

The fear of non-completion demands specific attention (Negovan, 2010). Challenges that may heighten the possibility of not completing one's degree are, for example, insufficient ex-ante information about the programme and the institution. Other concerns are the financing of studies, accommodation and transport (Yorke \& Longden, 2008). This finding is especially important within the context of many higher education institutions in South Africa, where a significant portion of the student population comprises firstgeneration students who are often far from their homes, in a new and demanding environment. The significance of being a newcomer to university life features in a number of studies internationally (Bewick, Koutsopoulou, Miles, Slaa \& Barkham, 2010). 
At a university in the United Kingdom, Bewick et al. (2010) investigated the psychological well-being of students from all faculties from pre-registration to the second semester of the third year of study. Results clearly showed that greater stress is experienced by students who start university compared to pre-university levels (Bewick et al., 2010). Interestingly, the levels of stress were higher in the first semester (Bewick et al., 2010). It is clear that university is a time of heightened levels of stress. Understanding these issues better can inform universities to facilitate the support necessary throughout students' studies to enable them to finish successfully. Furthermore, studies have found differences in the levels of happiness and optimism between male and female students (Srivastava \& Agarwal, 2013; Dar \& Wani, 2017). Dar and Wani (2017) found such a result for India.

Within the South African context, the subjective well-being of students is not yet receiving the same levels of research attention as elsewhere in the world. However, important work has been done in this regard. Notable is the work of Møller (1996), who investigated the dynamics of life satisfaction amongst students at the University of KwaZulu-Natal. Botha et al. (2013) focused their attention on satisfaction with residence life, in particular at Rhodes University in South Africa. Botha et al. (2013) pointed towards the importance of student attributes, such as demographics, and other variables, such as race, gender, sexual orientation, age, socioeconomic status, self-esteem, drug and alcohol use, learning style, and academic achievement. Variables endogenous to the institutions refer to issues such as living conditions, social spaces, leisure activities and the culture on campus (Botha et al., 2013).

Pretorius and Blaauw (2014) conducted an exploratory study on the subjective well-being of first-year students at a comprehensive higher education institution. Apart from the elements highlighted by previous international and local studies, they found additional variables in particular that are of importance for first-year students' subjective well-being. Positive aspects forthcoming from their results were the fact that the university was the institution of choice for the student; feeling 'at home'; knowing exactly how the university functions; and taking part in or watching sport (Pretorius \& Blaauw, 2014). Negative influences were identified as worries about tests, studying less than 10 hours per week and living on campus (Pretorius \& Blaauw, 2014).

Türkdoğan and Duru (2012, p. 2444) summarised the issue of subjective well-being of students, stating that:

It can be said that the students who have the ability to make choices and to express themselves freely, ... who feel themselves worthy and successful, who have enough safety and shelter conditions, and who have good relationships with special people in their lives, are more close to happiness than the others.

This study will use the variables identified in the international and South African literature as variables in econometric models to investigate the contributing factors playing a role in the levels of subjective well-being of students at one of South Africa's biggest universities. The choices of research population, research design and empirical strategy are discussed next. 


\section{Research Methodology}

\section{Survey instrument}

The research design for this study was quantitative. The study followed the example of the literature and utilised a survey-based research approach to investigate the possible variables contributing to the subjective well-being of first-year economics students within the context of related pressures on students in South Africa. To this end, a fit-for-purpose survey instrument was developed. The survey instrument evolved from the pioneering work of Van Zyl (2010). The survey was tested by conducting a trial run on a group of students and the survey was subsequently adjusted in multiple iterations. Potentially ambiguous questions and other problems in the survey instrument were identified and addressed.

After the development phase of the survey, the necessary ethical clearance was obtained from the relevant faculty's ethics committee. All associated ethical concerns were addressed, such as the need for anonymity and being voluntarily involved in the research project. A trained senior tutor was used to collect the data during tutorial sessions of the target group of students. The students have compulsory economics tutorial sessions every week. Before each session, the tutor explained the objectives of the study. The willingness of students to participate in the study was also confirmed before the survey was conducted.

The survey was completed every year from 2014 to 2016 by first-year economics students. The data for 2014 were collected in August 2014, whereas the data for 2015 and 2016 were collected in February 2015 and 2016, respectively. The data were captured and cleaned in the month after collection, in each of the respective years to provide an adequate dataset. The sample sizes for each year were 529 ( $24 \%$ of the research population), $641(29 \%)$ and $647(29.4 \%)$ students who completed the survey. This gave a total pooled sample of 1817 students ( $27.5 \%$ of the research population) over the three years. The following sections provide the details of the data and variables as well as the econometric framework of the empirical analysis.

\section{Data and variables}

The dependent variable in the study is labelled as 'Happiness'. The variable is a Likert scale measure of the self-reported subjective well-being (SWB) of individuals. The variable is based on question M5 of the first wave of the National Income Dynamics Study (NIDS), which reflects the subjective well-being of individuals: "Using a scale of 1 to 10 where 1 means "Very dissatisfied" and 10 means "Very satisfied", how do you feel about your life as a whole right now?' (NIDS, 2008:26). Figure 1 reveals the percentage of responses to the subjective well-being question per scale. Out of the 1817 responses in total over the three years, $18 \%$ of the students indicated that they were 'very satisfied' with their lives as a whole when the survey was conducted. Only $2 \%$ specified that they were 'very dissatisfied' with their lives when the survey was conducted. The majority of the student responses in the sample are clustered around the upper bounds of the research question, indicating the relative happiness of students at the institution. 


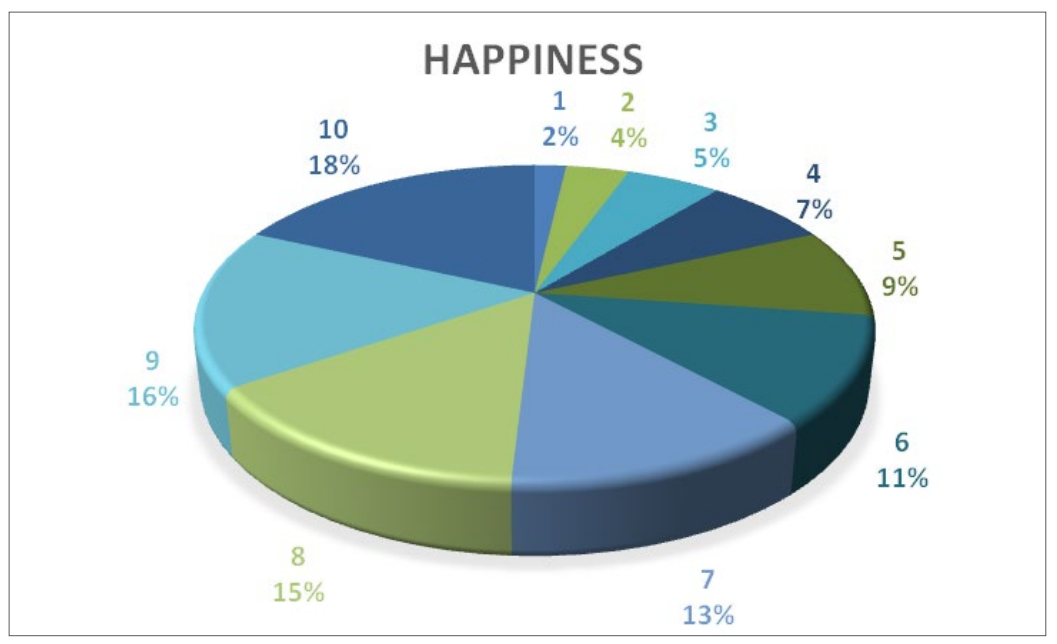

Figure 1: Summary of happiness amongst first-year economics students at a comprehensive institution, 2014-2016 (Source: Survey data)

Table 1 displays the basic demographic statistics of the students who participated in the survey over the respective sample years and in total. The ages of the respondents ranged from 17 to 35 years (with an average of 19 years), and there were slightly more female than male respondents. Furthermore, the majority of the respondents were South Africanlanguage and English-speaking. The respondents were mainly South African born: 100\% of respondents were from SA in 2014, 96.3\% in 2015 and $94.9 \%$ in 2016. The respondents in 2015 and 2016, who were not born in South Africa, were mostly from neighbouring countries. It can also be seen that, of the South African born respondents, most were born in Gauteng.

Table 1: Respondent demographic statistics

\begin{tabular}{|l|l|l|l|l|}
\hline & 2014 & 2015 & 2016 & Total \\
\hline Females (\%) & $320(60.5 \%)$ & $350(54.6 \%)$ & $353(54.6 \%)$ & $1023(56.3 \%)$ \\
\hline Males (\%) & $209(39.5 \%)$ & $291(45.4 \%)$ & $294(45.4 \%)$ & $794(43.7 \%)$ \\
\hline Total & $529(100 \%)$ & $641(100 \%)$ & $647(100 \%)$ & $1817(100 \%)$ \\
\hline African (\%) & $412(77.9 \%)$ & $506(78.9 \%)$ & $533(82.4 \%)$ & $1451(79.9 \%)$ \\
\hline Coloured (\%) & $24(4.5 \%)$ & $29(4.5 \%)$ & $28(4.3 \%)$ & $81(4.5 \%)$ \\
\hline Indian/Asian (\%) & $35(6.6 \%)$ & $49(7.6 \%)$ & $38(5.9 \%)$ & $122(6.7 \%)$ \\
\hline White (\%) & $53(10.0 \%)$ & $52(8.1 \%)$ & $45(7.0 \%)$ & $150(8.3 \%)$ \\
\hline Other (\%) & $5(1.0 \%)$ & $5(0.8 \%)$ & $3(0.5 \%)$ & $13(0.7 \%)$ \\
\hline Total & $529(100 \%)$ & $641(100 \%)$ & $647(100 \%)$ & $1817(100 \%)$ \\
\hline English & $206(38.9 \%)$ & $243(37.9 \%)$ & $220(34.0 \%)$ & $669(36.8 \%)$ \\
\hline Sesotho & $36(6.8 \%)$ & $36(5.6 \%)$ & $39(6.0 \%)$ & $111(6.1 \%)$ \\
\hline
\end{tabular}




\begin{tabular}{|l|l|l|l|l|}
\hline & 2014 & 2015 & 2016 & Total \\
\hline Sepedi & $48(9.1 \%)$ & $45(7.0 \%)$ & $67(10.4 \%)$ & $160(8.8 \%)$ \\
\hline IsiZulu & $99(18.7 \%)$ & $110(17.2 \%)$ & $135(20.9 \%)$ & $344(18.9 \%)$ \\
\hline IsiNdebele & $9(1.7 \%)$ & $2(0.3 \%)$ & $6(0.9 \%)$ & $17(0.9 \%)$ \\
\hline Xitsonga & $26(4.9 \%)$ & $25(3.9 \%)$ & $30(4.6 \%)$ & $81(4.5 \%)$ \\
\hline Afrikaans & $21(4.0 \%)$ & $23(3.6 \%)$ & $8(1.2 \%)$ & $52(2.9 \%)$ \\
\hline Setswana & $35(6.6 \%)$ & $70(10.9 \%)$ & $53(8.2 \%)$ & $158(8.7 \%)$ \\
\hline IsiXhosa & $22(4.2 \%)$ & $29(4.5 \%)$ & $37(5.7 \%)$ & $88(4.8 \%)$ \\
\hline Tshivenda & $15(2.8 \%)$ & $29(4.5 \%)$ & $17(2.6 \%)$ & $61(3.4 \%)$ \\
\hline SiSwati & $11(2.1 \%)$ & $22(3.4 \%)$ & $20(3.1 \%)$ & $53(2.9 \%)$ \\
\hline Shona & $0(0.0 \%)$ & $4(0.6 \%)$ & $9(1.4 \%)$ & $13(0.7 \%)$ \\
\hline Other & $1(0.2 \%)$ & $3(0.5 \%)$ & $6(0.9 \%)$ & $10(0.6 \%)$ \\
\hline Total & $529(100 \%)$ & $641(100 \%)$ & $647(100 \%)$ & $1817(100 \%)$ \\
\hline Gauteng & $294(55.6 \%)$ & $343(55.6 \%)$ & $361(59.5 \%)$ & $998(56.9 \%)$ \\
\hline Mpumalanga & $51(9.6 \%)$ & $51(8.3 \%)$ & $52(8.6 \%)$ & $154(8.8 \%)$ \\
\hline KZN & $54(10.2 \%)$ & $64(10.4 \%)$ & $67(11.0 \%)$ & $185(10.6 \%)$ \\
\hline EC & $19(3.6 \%)$ & $18(2.9 \%)$ & $23(3.8 \%)$ & $60(3.4 \%)$ \\
\hline Limpopo & $75(14.2 \%)$ & $83(13.5 \%)$ & $69(11.4 \%)$ & $227(12.9 \%)$ \\
\hline NW & $23(4.3 \%)$ & $34(5.5 \%)$ & $20(3.3 \%)$ & $77(4.4 \%)$ \\
\hline Free State & $11(2.1 \%)$ & $14(2.3 \%)$ & $6(1.0 \%)$ & $31(1.8 \%)$ \\
\hline NC & $1(0.2 \%)$ & $4(0.6 \%)$ & $3(0.5 \%)$ & $8(0.5 \%)$ \\
\hline WC & $1(0.2 \%)$ & $6(1.0 \%)$ & $6(1.0 \%)$ & $13(0.7 \%)$ \\
\hline Total & $529(100 \%)$ & $617(100 \%)$ & $607(100 \%)$ & $1753(100 \%)$ \\
\hline
\end{tabular}

Source: Survey data

The survey instrument included various questions in order to identify possible variables that affect student happiness. The questions in the survey included demographic details, variables that normally are of concern for students, social and academic interaction variables, travel and living arrangements and university-related variables. Table 2 encapsulates the explanatory variables considered for the empirical analysis.

Table 2: Explanatory variables considered in the models

\begin{tabular}{|l|l|}
\hline Variable & Description \\
\hline & Demographic variables \\
\hline Age & $\begin{array}{l}\text { The age of students during the time of the survey. The } \\
\text { mathematical squared value (Agesq) was also included in the } \\
\text { empirical models as suggested in the SWB literature. }\end{array}$ \\
\hline Gender & Male or female \\
\hline
\end{tabular}




\begin{tabular}{|c|c|}
\hline Variable & Description \\
\hline Language & $\begin{array}{l}\text { Predominant language of student - English, Sesotho, Sepedi, } \\
\text { IsiZulu, IsiNdebele, Xitsonga, Afrikaans, Setswana, IsiXhosa, } \\
\text { Tshivenda, SiSwati, Shona and other }\end{array}$ \\
\hline Race & African, coloured, white, Indian/Asian and other \\
\hline Province & $\begin{array}{l}\text { The majority of the respondents were from South Africa. } \\
\text { Categories for each of the nine provinces were included } \\
\text { - Gauteng, Mpumalanga, KwaZulu-Natal, Eastern Cape, } \\
\text { Limpopo, North West, Free State, Northern Cape and } \\
\text { Western Cape. }\end{array}$ \\
\hline \multicolumn{2}{|r|}{ Concerns } \\
\hline Finances & Worries about the financing of studies. \\
\hline Food problems & Problems affording or attaining food. \\
\hline Test worries & Worries about upcoming tests. \\
\hline Transport & Problems with transport to and from university. \\
\hline \multicolumn{2}{|r|}{ Interaction: Social or academic } \\
\hline Contact & $\begin{array}{l}\text { Personal contact was made with a lecturer and/or tutor } \\
\text { during the academic year. }\end{array}$ \\
\hline Culture & $\begin{array}{l}\text { Participation in or attendance of cultural activities at the } \\
\text { university. }\end{array}$ \\
\hline Sport & $\begin{array}{l}\text { Participation in or attendance of sport activities at the } \\
\text { university. }\end{array}$ \\
\hline Friends & Students who have made friends at the university. \\
\hline First-year seminar & $\begin{array}{l}\text { Attendance of the First-year seminar (FYS) in January before } \\
\text { the commencement of lectures. }{ }^{3} \text {. }\end{array}$ \\
\hline Missed & $\begin{array}{l}\text { The number of tutorials and lectures that were missed } \\
\text { during a normal week. }\end{array}$ \\
\hline \multicolumn{2}{|r|}{ Travel and living arrangements } \\
\hline Distance campus & $\begin{array}{l}\text { Distance of residence from campus - on campus or within } \\
\text { walking distance, } 30 \text { minutes or less from campus or more } \\
\text { than } 30 \text { minutes from campus. }\end{array}$ \\
\hline Happy live & Happiness in terms of current residence. \\
\hline Live & $\begin{array}{l}\text { Place of residence - on campus, home, commune, family or } \\
\text { other. }\end{array}$ \\
\hline Transport used & $\begin{array}{l}\text { Type of transport mostly used to get to campus - taxi, } \\
\text { private car, walking or other. }\end{array}$ \\
\hline
\end{tabular}

3 During these sessions there are opportunities to meet your fellow students through a team-building activity and people get the opportunity to listen to various role players at the University in terms of its everyday activities and functions. 


\begin{tabular}{|l|l|}
\hline Variable & Description \\
\hline Choice & Other university related variables \\
\hline Expect & Whether the university was the institution of choice or not. \\
\hline Study hours & Students understand what is expected of them from lecturers. \\
\hline Home & $\begin{array}{l}\text { Hours spent studying outside of class time, per week - less } \\
\text { than } 10,10 \text { to } 15,16 \text { to } 25,26 \text { to } 35 \text { and more than } 35 \text { hours. }\end{array}$ \\
\hline University function & Feeling 'at home' at the university. \\
\hline Satisfaction & Understand how the university functions. \\
\hline
\end{tabular}

Source: Survey instrument

The econometric models that were used in the study will be discussed next.

\section{Econometric framework}

In empirical studies that estimate subjective well-being, normally two types of models are used: ordinary least squares (OLS) regressions and ordered response models. Ordered response models take the qualitative and ordinal nature of the dependent variable into account. This study followed the practice of estimating both the OLS and the ordered response models. The coefficients of the OLS model are mostly used for interpretation.

According to Long and Freese (2006), the ordered probit model is specified as follows:

$$
y_{i}^{+}=\beta X_{i}+\varepsilon_{i}
$$

where $y_{i}^{+}$is an unobservable latent variable that represents the happiness of student $i$ ordered from 1 to 10 , and $X_{i}$ represents a vector of context-specific and basic explanatory variables. Furthermore, $\beta$ represents a vector of coefficients for each variable in the vector $X_{i}$ and $\varepsilon_{i}$ represents a random and normally distributed error term. The categories of the observed variable $y_{i}^{+}$are mapped from the probability outputs corresponding to the following cut points (Long \& Freese, 2006):

1 if $y_{i}^{+}<\tau_{\mathbf{1}} @ 2$ if $\tau_{\mathbf{1}} \leq y_{i}^{+}<\tau_{\mathbf{2}} @ 3$ if $\tau_{\mathbf{2}} \leq y_{i}^{+}<\tau_{\mathbf{3}} @ 4$ if $\tau_{\mathbf{3}} \leq y_{i}^{+}<\tau_{\mathbf{4}} @ 5$ if $\tau_{\mathbf{4}} \leq y_{i}^{+}<\tau_{\mathbf{5}}$ @6 if $\tau_{5} \leq y_{i}^{+}<\tau_{6} @ 7$ if $\tau_{6} \leq y_{i}^{+}<\tau_{7} @ 8$ if $\tau_{7} \leq y_{i}^{+}<\tau_{8} @ 9$ if $\tau_{8} \leq y_{i}^{+}<\tau_{9} @ 10$ if $y_{i}$

Initially, all explanatory variables were included in the pooled OLS model and the pooled ordered probit model. Thereafter, the individual annual models were considered and compared for the ordered probit models only. The results of the final regression models are discussed in the next section.

\section{Results and Discussion}

All variables were considered in the initial OLS and ordered probit model for the pooled data. Thereafter, the insignificant variables were omitted. The results are represented in Table 3. The same variables identified in the pooled models were tested for significance for the annual individual ordered probit models and the results are presented in Table 4. 
The results will be discussed according to the general themes of variables identified in the data and variables section, i.e. demographic variables, concerns, interaction (social or academic), travel and living arrangements and other university related variables.

Table 3: Final pooled model results

\begin{tabular}{|c|c|c|c|c|c|c|}
\hline & & LS & & Ord & ed Probit & \\
\hline & Coef & Prob & & Coef & Prob & \\
\hline $\mathrm{C}$ & 1.3332 & 0.5923 & & & & \\
\hline Age & 0.4061 & 0.0721 & $\star$ & 0.2597 & 0.0705 & $\star$ \\
\hline Agesq & -0.0094 & 0.0653 & $\star$ & -0.0059 & 0.0672 & $\star$ \\
\hline Finances & -0.1801 & 0.0559 & $\star$ & -0.0955 & 0.1040 & \\
\hline Test worries & -0.6446 & 0.0000 & $\star \star \star$ & -0.4300 & 0.0000 & $\star \star \star$ \\
\hline Friends & 0.2633 & 0.0929 & $\star$ & 0.1497 & 0.1249 & \\
\hline First-year seminar & 0.1770 & 0.0852 & $\star$ & 0.1178 & 0.0659 & $\star$ \\
\hline Distance campus & -0.2835 & 0.0051 & $\star \star$ & -0.1777 & 0.0048 & $\star \star \star$ \\
\hline Happy live & 0.4571 & 0.0000 & $\star \star \star$ & 0.2661 & 0.0000 & $\star \star \star$ \\
\hline Live commune & 0.3520 & 0.0016 & $\star \star \star$ & 0.2281 & 0.0010 & $\star \star \star$ \\
\hline Expect & 0.3794 & 0.0182 & $\star \star$ & 0.2080 & 0.0376 & $\star \star$ \\
\hline Home & 0.4071 & 0.0003 & $\star \star \star$ & 0.2482 & 0.0004 & $\star \star \star$ \\
\hline Study 25 to $35 \mathrm{p} / \mathrm{w}$ & 0.4302 & 0.0046 & $\star \star \star$ & 0.2651 & 0.0051 & $\star \star \star$ \\
\hline Satisfied with university & 0.9213 & 0.0000 & $\star \star \star$ & 0.5830 & 0.0000 & $\star \star \star$ \\
\hline Dissatisfied with university & -1.7030 & 0.0000 & $\star \star \star$ & -0.9073 & 0.0000 & $\star \star \star$ \\
\hline R-squared & & 0.2523 & & & & \\
\hline Adjusted R-squared & & 0.2441 & & & & \\
\hline Pseudo R-squared & & & & & 0.0685 & \\
\hline Sample size & 1817 & & & 1817 & & \\
\hline
\end{tabular}

Table 4: Annual ordered probit models results

\begin{tabular}{|c|c|c|c|c|c|c|c|c|}
\hline & \multicolumn{3}{|c|}{2014} & \multicolumn{3}{|c|}{2015} & \multicolumn{2}{|c|}{2016} \\
\hline & Coef & Prob & & Coef & Prob & & Coef & Prob \\
\hline Age & 0.9612 & 0.248 & & 0.4052 & 0.0326 & $\star \star$ & 0.1103 & 0.6411 \\
\hline Agesq & -0.0227 & 0.274 & & -0.0089 & 0.0344 & $\star \star$ & -0.0029 & 0.6014 \\
\hline Finances & & & $\#$ & -0.1606 & 0.0581 & $\star$ & -0.0536 & 0.5177 \\
\hline Test worries & -0.2960 & 0.0020 & $\star \star \star$ & -0.3263 & 0.0007 & $\star \star \star$ & -0.5248 & $0.0000 \star \star \star$ \\
\hline Friends & 0.2191 & 0.205 & & 0.1326 & 0.3726 & & 0.1507 & 0.2530 \\
\hline First-year seminar & 0.1028 & 0.3317 & & 0.1324 & 0.1399 & & 0.1084 & 0.2397 \\
\hline
\end{tabular}




\begin{tabular}{|c|c|c|c|c|c|c|c|c|c|}
\hline & \multicolumn{3}{|c|}{2014} & \multicolumn{3}{|c|}{2015} & \multicolumn{3}{|c|}{2016} \\
\hline & Coef & Prob & & Coef & Prob & & Coef & Prob & \\
\hline Distance campus & -0.0076 & 0.9418 & & -0.2880 & 0.0029 & $\star \star \star$ & -0.0926 & 0.2770 & \\
\hline Happy live & 0.4380 & 0.0000 & $\star \star \star$ & 0.1911 & 0.0414 & $\star \star$ & 0.3196 & 0.0005 & $\star \star \star$ \\
\hline Live commune & 0.0198 & 0.8626 & & 0.2800 & 0.0069 & $\star \star \star$ & 0.2087 & 0.0323 & $\star \star$ \\
\hline Expect & -0.0675 & 0.6818 & & 0.2601 & 0.0712 & $\star$ & 0.1857 & 0.1875 & \\
\hline Home & 0.3166 & 0.0050 & $\star \star$ & 0.2852 & 0.0044 & $\star \star \star$ & 0.2166 & 0.0285 & $\star \star$ \\
\hline $\begin{array}{l}\text { Study } 25 \text { to } 35 \\
\mathrm{p} / \mathrm{w}\end{array}$ & -0.0051 & 0.9688 & & 0.2905 & 0.0356 & $\star \star \star$ & 0.2804 & 0.0338 & $\star \star$ \\
\hline $\begin{array}{l}\text { Satisfied with } \\
\text { university }\end{array}$ & 0.4570 & 0.0000 & $\star \star \star$ & 0.6339 & 0.0000 & $\star \star \star$ & 0.5686 & 0.0000 & $\star \star \star$ \\
\hline $\begin{array}{l}\text { Dissatisfied with } \\
\text { university }\end{array}$ & -0.5738 & 0.0156 & $\star \star$ & -0.6680 & 0.0106 & $\star \star$ & -0.9358 & 0.0000 & $\star \star \star$ \\
\hline Pseudo R-squared & & 0.0517 & & & 0.0659 & & & 0.0737 & \\
\hline Sample size & 529 & & & 641 & & & 647 & & \\
\hline
\end{tabular}

Source: Survey Instrument

\section{Demographic Variables}

The only demographic variables that were significant in the pooled OLS and ordered probit models were age and age squared of the respondents. It is customary to include the age variable as well as the mathematical squared value of age as two separate variables in econometric models to accommodate for the potential non-linearity in the relationship with the dependant variable (therefore a quadratic relationship). If the age variable has a positive relationship with the dependent variable and the squared variable a negative relationship, it means that, as people get older, the effect of age is lessened on the dependent variable. However, if both the age and the age squared variables have a positive effect on the dependent variable, the effect is stronger on the dependent variable as people get older. In the individual annual models, age and age squared were only significant in 2015 . The age and age squared variables respectively show a positive and negative relationship with happiness. The quadratic relationship therefore indicates that, as students get older, the effect of age on happiness is reduced. Considering that the sample is for a large part a homogenous group, it is not surprising that there are no other significant demographic variables.

\section{Concerns}

Finances and test worries are the two concerns variables that were significant in the pooled OLS model. The finance variable represents worries that students experience in terms of the financing of their studies. Test worries reflect students' fears about upcoming tests. Test worries are very significant in the pooled ordered probit model, but the finances 
variable is only significant at the $11 \%$ level of significance. It is noteworthy that the finances variable is only significant in the annual ordered probit model for 2015 (the finances variable was unfortunately not included in the 2014 survey), but it was no longer significant in the 2016 ordered probit model.

The significance of the finances variable in 2015 could be a reflection of the start of the \#FeesMustFall campaign. Although the \#FeesMustFall protests only occurred in the middle of October of 2015, it appears that the worries regarding the increase of fees were already playing a role at the start of the year when the surveys were conducted. Furthermore, the non-significance in 2016 could be ascribed to the announcement of no tuition-fee increases for 2016 by the South African government. Worries regarding upcoming tests are a significant factor influencing the happiness of students negatively, as it is highly significant throughout all the individual sample years, respectively.

\section{Interaction: social or academic}

In the pooled OLS model, one social interaction variable, friends, is significant with the expected sign. This variable indicates whether a particular student has already made friends at university. When the pooled ordered probit model was estimated, the significance of friends changed to significant only at a $13 \%$ level of significance. Friends turned out to be insignificant in the annual ordered probit models. Other studies (for example, Mangeloja \& Hirvonen, 2007, and Chan et al., 2005) emphasised that social relationships were an imperative determinant of happiness and therefore the insignificance of the friends variable from the annual ordered probit models is surprising. It seems that making friends does not have a direct influence on the SWB of students at this institution. This is an important avenue for further research.

Furthermore, one academic interaction variable, first-year seminar (FYS), is significant with the expected sign in the pooled OLS as well as the ordered probit model. FYS was not significant in the annual ordered probit models. The FYS variable is indicative of the annual orientation session that takes place at the beginning of the academic year. This gathering serves as an information session to students in terms of the everyday activities and functions of the university. There is also an opportunity for students who are enrolled for the same programmes to meet each other and take part in team-building activities. The insignificance of this variable in the annual ordered probit models shows that this engagement does not have a direct effect on the SWB of students.

\section{Travel and living arrangements}

In terms of variables that are categorised under travel and living arrangements, there are three variables that were significant in the pooled OLS and ordered probit models. The first is the distance campus variable, which indicates how far students live from the campus. On campus and within walking distance were collapsed into one category and it shows a negative relationship with happiness; therefore, students' happiness is decreased when they live on campus or close to campus. This finding could allude to the questionable quality 
of student accommodation in and around campuses (as reported in the Soudien report in 2008). The within walking distance variable and its significant negative relationship with happiness reflect the issues of overcrowding and increased crime levels experienced on and around the campus. Incidents of crime and overcrowded student accommodation were often reported in the local media, government departments and academic literature for the last decade. See, for example, DHET (2011), Mbara and Celliers (2013) and De Villiers (2018). These results accentuate the need for university management to put further emphasis on issues of student safety.

The other two travel and living arrangement variables that were significant in both the pooled OLS and the ordered probit model were happy life and live commune. The happy live variable indicates the happiness of students in terms of their current residence. This variable was also significant in all three years of the annual models. The live commune variable represents students who live in communes, and this variable was only significant in 2015 and 2016. These two variables emphasise the importance of living arrangements in the happiness of students.

\section{Other university-related variables}

The last category of variables, which are all university-related, has the most significant variables. Expect, home, study 25 to 35 p/w, satisfied with university and unsatisfied with university were all significant in the pooled OLS and ordered probit models. The expect variable refers to the situation where students completely understand what is expected of them from their lecturers. This variable was only significant in the 2016 annual model. Home, satisfied with university, and unsatisfied with university were all significant in each one of the annual models. The home variable refers to students feeling "at home" at the university. The two satisfaction variables denote the overall level of satisfaction of the students' experience at the university. Lastly, the study 25 to $35 \mathrm{p} / \mathrm{w}$ variable was not significant in 2015, but it was significant in 2016 and 2017. This variable specifically refers to the hours spent studying outside of class time, per week. The study by Mangeloja and Hirvonen (2007) revealed that one of the most important impacts on students' happiness is the educational environment. The adjustment process to the new environment at university will be much easier on students if they feel at home at the university and know what is expected of them. These results raise important considerations for university management and even academic units and faculties.

\section{Conclusions, Policy Considerations and Areas for Further Research}

One of the main challenges that is facing the higher education sector in South Africa is reflected in the results of this study: finances. Issues of finances for university students constituted a significant negative contributor to the SWB of students in 2015 - as was evident in the \#FeesMustFall campaign, which was directly linked to this ongoing problem.

The SWB of students is influenced positively by their living arrangements (those who are happy with their current residence and those that live in a commune) as well 
as variables that have a direct influence on the educational environment in which they operate. Students will adjust to the new university environment more easily if they feel 'at home' at the university and know exactly what is expected of them. Negative variables that influence the SWB of students include concerns regarding finances and upcoming tests. Living on the campus itself or if you live within walking distance of campus also influenced SWB negatively. The results in terms of the off-campus variable and the issue of crime and overcrowding are a call to university management to increase its levels of cooperation with law enforcement agencies and the metro in order to improve the experience of those living off campus. In the words of a police officer quoted by De Villiers (2018), "They (students) have a lot to worry about. They don't need to worry about being robbed."

The insignificance of the FYS in the annual ordered probit models suggests that the frequency of these first-year seminars may not be enough for students to gain the intended benefit of engaging with fellow students and getting to know the inner workings of the university. Supplementing these with additional seminars in the second semester may enhance the benefit for the students and impact positively on their first-year experience and its concomitant challenges.

Overall, the results show that every possible effort is needed to increase students' chances of achieving the success expected of them by the social norms and structures of our society. This may ultimately be the best way to enhance their experience of student life and their associated SWB. Added to that, academic success is an important factor in achieving the private and social returns on the investment in South Africa's higher education sector that our limited resources require of us. Ultimately, that is the only way to ensure that future generations of students face less of the added pressures that weigh first-year students down, making it difficult to go through the doors of learning with confidence and a high likelihood of succeeding.

\section{References}

Bantjes, J.R., Kagee, A., McGowan, T. \& Steel, H. (2016). Symptoms of posttraumatic stress, depression, and anxiety as predictors of suicidal ideation amongst South African university students. Journal of American College Health, 64(6), 429-437. https://doi.org/10.1080/07448481.2016.1178120

Bewick, B., Koutsopoulou, G., Miles, J., Slaa, E. \& Barkham, M. (2010). Changes in undergraduate students' psychological well-being as they progress through university. Studies in Higher Education, 35(6), 633-645. https://doi.org/10.1080/03075070903216643

Blaauw, D. \& Pretorius, A. (2013). The determinants of subjective well-being in South Africa - an exploratory enquiry. Journal of Economic and Financial Sciences, 6(1), 179-194. https://doi.org/10.41 02/jef.v6i1.283

Botha, F, Snowball, J., De Klerk, V. \& Radloff, S. (2013). Determinants of student satisfaction with campus residence life at a South African university. Economic Research Southern Africa (ERSA) (Working paper no. 388).

Chan, G., Miller, P. \& Tcha, M. (2005). Happiness in university education. International Review of Economics Education, 4(1), 20-45. https://doi.org/10.1016/S1477-3880(15)30139-0

Chow, H. (2005). Life satisfaction amongst university students in a Canadian prairie city: A multivariate analysis. Social Indicators Research, 70(2), 139-150. https://doi.org/10.1007/s11205-004-7526-0 
Christie, H., Tett, L., Cree, V.E., Hounsell, J. \& McCune,V. (2008). 'A real rollercoaster of confidence and emotions': learning to be a university student. Studies in Higher Education, 33(5), 567-581. https://doi. org $/ 10.1080 / 03075070802373040$

Cox, K. (2012). Happiness and unhappiness in the developing world: life satisfaction amongst sex workers, dump-dwellers, urban poor, and rural peasants in Nicaragua. Journal of Happiness Studies, 13(1), 103-128. https://doi.org/10.1007/s10902-011-9253-y

Dar, A.A. \& Wani, M.A. (2017). Optimism, happiness, and self-esteem amongst university students. Indian Journal of Positive Psychology, 8(3), 300-304. https://doi.org/10.15614/ijpp/2017/v8i3/161893

Dave, R., Tripathi, K.N., Singh, P. \& Udainiya, R. (2011). Subjective well-being, locus of control and general self-efficacy amongst university students. Amity Journal of Applied Psychology, 2(1), 28-32.

De Villiers, R. (2018). Police identify student crime hotspot in Auckland Park. https://bit.ly/3d9AK3O [Accessed 25 February 2019].

DHET (Department of Higher Education and Training) (2011). Report on the Ministerial Committee for the review of the provision of student housing at South African universities. https://www.cput. ac.za/storage/services/procurement/ministerial_report_housing.pdf [Accessed 25 February 2019].

Diener, E., Diener, M. \& Diener, C. (2009). Factors predicting subjective well-being of nations. Social Indicators Research Series, 38, 43-70. https://doi.org/10.1007/978-90-481-2350-6_2

Dolan, P., Peasgood, T. \& White, M. (2008). Do we really know what makes us happy? A review of the economic literature on the factors associated with subjective well-being. Journal of Economic Psychology, 29(1), 94-122. https://doi.org/10.1016/j.joep.2007.09.001

Easterlin, R.A. (1974). Does economic growth improve the human lot? Some empirical evidence. In: P.A. David \& M.W. Reder (Eds.), Nations and households in economic growth: Essays in honour of Moses Abramovitz. New York: Academic Press, 89-125. https://doi.org/10.1016/B978-0-12-2050503.50008-7

Easterlin, R.A. (2001). Editorial: Subjective well-being and economic analysis: a brief introduction. Journal of Economic Behavior \& Organization, 45(3), 225-226. https://doi.org/10.1016/S0167-2681(01)00143-3

Eckersley, R. (2011).A new narrative of young people's health and well-being. Journal of Youth Studies, 14(5), 627-638. https://doi.org/10.1080/13676261.2011.565043

Flynn, D.M. \& MacLeod, S. (2015). Determinants of happiness in undergraduate university students. College Student Journal, 49(3), 452-460.

Frey, B. \& Stutzer, A. (2002). Happiness and Economics. Princeton University Press.

HESA (Higher Education of South Africa) (2005). SA higher education. http://web.archive.org/web/ 20050301015907/; http://www.sauvca.org.za/highered/ [Accessed 13 February 2014].

Kahneman, D. \& Krueger,A.B. (2006). Developments in the measurement of subjective well-being. Journal of Economic Perspectives, 20(1), 3-24. https://doi.org/10.1257/089533006776526030

Long,J.S. \& Freese,J. (2006). Regression Models for Categorical Dependent Variables using Stata. Texas: Stata Press.

Luescher,T.M., Schreiber, B. \& Moja,T. (2018). Towards student well-being and quality services in student affairs in Africa. Journal of Student Affairs in Africa, 6(2), v-viii. https://doi.org/10.24085/jsaa.v6i2.3317

MacKerron, G. (2012). Happiness economics from 35,000 feet. Journal of Economic Surveys, 26(4), 705-735. https://doi.org/10.1111/j.1467-6419.2010.00672.x

Mangeloja, E. \& Hirvonen, T. (2007). What makes university students happy? International Review of Economics Education, 6(2), 26-41. https://doi.org/10.1016/S1477-3880(15)30105-5

Mbara, T.C. \& Celliers, C. (2013). Travel patterns and challenges experienced by University of Johannesburg off-campus students. Journal of Transport and Supply Chain Management, 7(1), Art. \#114, 8 pages. https://doi.org/10.4102/jtscm.v7i1.114 
Michalos, A.C. (2008). Education, happiness and wellbeing. Social Indicators Research, 87(3), 347-366. https://doi.org/10.1007/s11205-007-9144-0

Møller, V. (1996). Life satisfaction and expectations for the future in a sample of university students: A research note. South African Journal of Sociology, 27(1), 16-26. https://doi.org/10.1080/02580144.1 996.10430699

Negovan,V. (2010). Dimensions of students' psychosocial well-being and their measurement: validation of a students' psychosocial well-being inventory. Europe's Journal of Psychology, 6(2), 85-104. https://doi. org/10.5964/ejop.v6i2.186

NIDS (National Income Dynamics Study) (2008). Adult questionnaire, National Income Dynamics Survey. SALDRU, UCT School of Economics, Cape Town.

Nielsen, I., Newman,A., Smyth, R., Hirst, G. \& Heilemann, B. (2017). The influence of instructor support, family support and psychological capital on the well-being of postgraduate students: a moderated mediation model, Studies in Higher Education, 42(11), 2099-2115. https://doi.org/10.1080/030750 79.2015.1135116

Pretorius, M. \& Blaauw, P.F. (2014). Happiness amongst first-year students at a comprehensive tertiary institution - an exploratory study. Journal of Economic and Financial Sciences, 7(2), 467-484. https://doi. org/10.4102/jef.v7i2.151

Simkins, C. (2016). Funding. South African higher education reviewed: two decades of democracy. In: Kagisano (10), Council on Higher Education, 39-115.

Soudien, C. (2008). Report of the ministerial committee on transformation and social cohesion and the elimination of discrimination in public higher education institutions. https://bit.ly/2zHYhvi [Accessed 8 October 2019].

Srivastava, N. \& Agarwal, S. (2013). Self-esteem amongst young adults: a comparative study. International Journal of Humanities and Social Sciences Invention, 2(3), 59-61.

Türkdoğan, T. \& Duru, E. (2012). The role of basic needs fulfilment in prediction of subjective well-being amongst university students. Educational Sciences:Theory \& Practice, 12(4), 2440-2446.

Van Zyl,A. (2010). The predictive value of pre-entry attributes for student academic performance in the South African context. DEd et Phil thesis, University of Johannesburg, South Africa.

Yorke, M. \& Longden, B. (2008). The first-year experience of higher education in the UK, final report. The Higher Education Academy, York, United Kingdom.

\section{How to cite:}

Pretorius, M. \& Blaauw, D. 2020. Financial Challenges and the Subjective Well-being of First-year Students at a Comprehensive South African University. Journal of Student Affairs in Africa, 8(1), 47-63. DOI: $10.24085 /$ jsaa.v8i1.3824 
